\title{
Development of Flight Multifunctional Indicator Based on A320 and B737 NG Flight Indicator
}

\author{
A R Pandie ${ }^{1,}{ }^{*}$, and A V Kirillov ${ }^{2}$ \\ 1 Department of Aeronautics and Astronautics, Tokyo Metropolitan University, 6-6 Asahigaoka, Hino-shi, Tokyo, \\ 191-0065 Japan \\ 2 Institute of Aviation Engineering, Samara National Research University, Moskovskoe shosse, 34, Samara, 443086, \\ Russia \\ * Correspondence: pandie-andry@ed.tmu.ac.jp
}

Received: 12 May 2021; Accepted: 30 May 2021; Published: 30 June 2021

\begin{abstract}
The objectives of this research are: to know the concept of modeling and simulation the cockpit display based on disadvantages and differences between A320 and B737NG; to offer the development and new technology to design the development (new) flight instruments of the display based on Airbus A320 and Boeing B737 NG flight instrument technology. Methodologies that have been used in this research are literature review, interview/discussion/questionnaire, and descriptive analysis. Questionnaire towards the users/pilots who flies airplane A320 or B737 NG. For the questionnaire, the Likert-scale method is utilized to collect data and information. This research result's in finding that: 1. the technology of flight instrument system between A320 and B737 NG visually displays similarity with several differences such as ergonomic side, ECAM technology, and VSD technology. 2. Based on works of literature review and response from the users/pilots, the author finds and proposes several technologies or requirements to apply in the new type model of PFD and Multi-function Display, they are including: PFD and MFD merged into one display only with some additional menu buttons; ECAM + engine warning display, ECAM + systems display, and digital instruction to solve the problem merged into one display only with some additional buttons; display design is using the fully digital display, computerized system, LCD technology, VSD, and EHSI technology, and layout display is using configuration "basic T"; standby flight instrument merged into one display only with some additional menu buttons.
\end{abstract}

Keywords: A320, B737 NG, cockpit display, ECAM, indicator, instrument, Likert-scale, VSD

\section{Introduction}

The instrument on an airplane is very important if the airplane is flying at night, bad weather, with a very long distance by navigating the sea and land that is so wide it feels very difficult without being helped by equipment called an instrument. The instrument is devices physically contained in one unit and devices composed of two or more physically separate units or components connected [1-3].

Electronic displays can provide many innovative display flexibilities and features that were not possible with traditional displays. Technology improvements in display design and integration can enhance pilot performance and improve situation awareness when innovations are designed using sound processes and appropriate design criteria that account for human performance [[4-6].

Nowadays, in the world, we know the two largest civil aircraft manufacturers are known as Airbus and Boeing. Both of these manufacturers are famous for their high-aviation technology. One of these high technologies is applied to the flight instrument. The plan, in this research, will be to 
study the high technology used by Airbus and Boeing in their flight instrument technology. No matter how high the technology that is owned by a product, it certainly has its advantages and disadvantages that need to be improved to get high-quality and high-precision new technology compared to the previous technologies [7-9].

\section{Materials}

The flight instruments include pitot-static data, air data, attitude and heading data, and electronic flight instruments system information and covers the basic flight instruments (digital/analog) and related components that provide the information to the flight crew.

\subsection{Flight Instrument of Airbus A320}

This cockpit has six displays which include two Primary Flight Displays (PFD) and two MultiFunction Displays (MFD) and one EICAS display, as presented on Fig. 1, Fig. 2, Table 1 and Table 2.

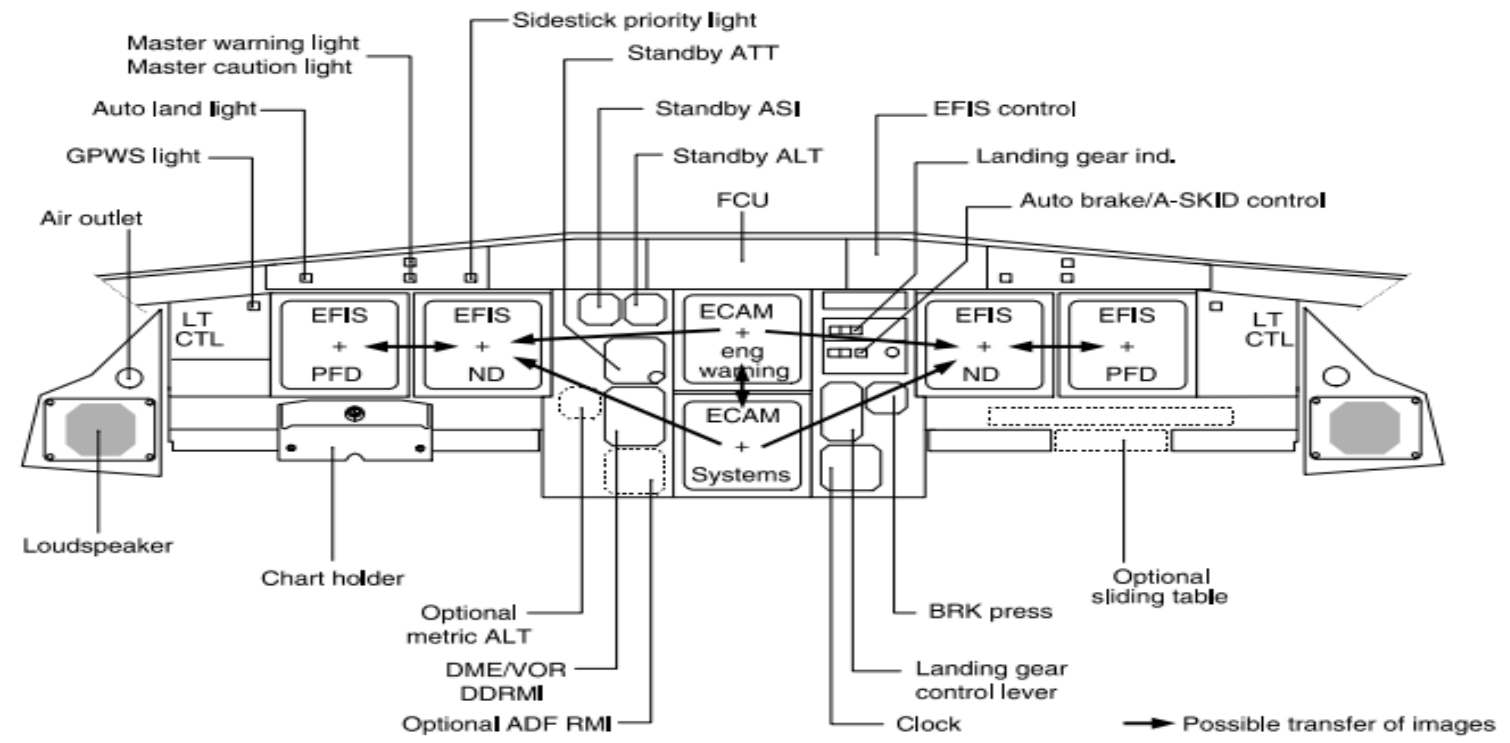

Figure 1. A320 main instrument panels [10]

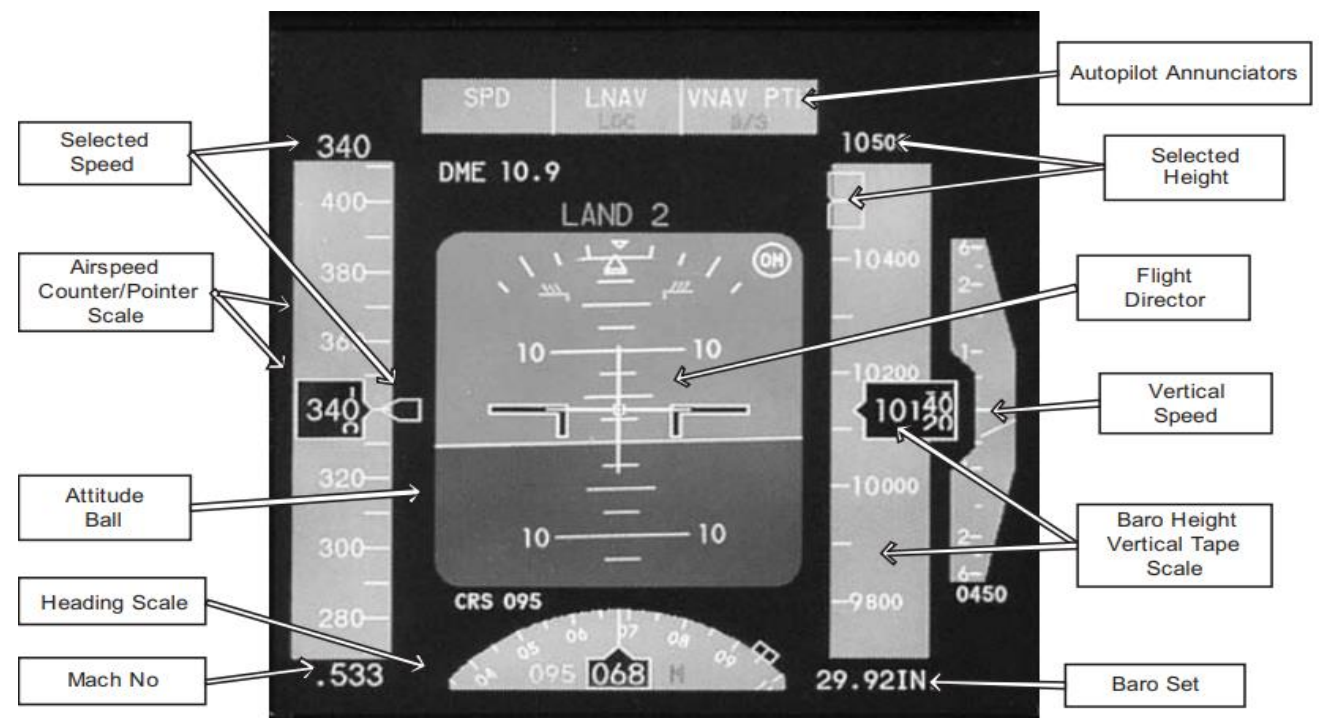

Figure 2. A320 PFD [11-13] 
Table 1. A320 multifunction display criterion [14-20]

\begin{tabular}{|c|c|c|}
\hline № & Components & Description \\
\hline 1 & $\begin{array}{l}\text { Main instrument } \\
\text { panel }\end{array}$ & $\begin{array}{l}\text { Loudspeaker, air outlet, GPWS light, clock, auto-land light, master } \\
\text { warning light and master caution light, chart holder, side-stick } \\
\text { priority light, standby attitude, standby ASI (air speed indicator), } \\
\text { standby altitude, optional metric altitude, DME/VOR DDRMI, } \\
\text { optional ADF RMI, FCU, EFIS + PFD display, EFIS + ND display, } \\
\text { ECAM engine warning display, ECAM + systems display, EFIS } \\
\text { control, landing gear indicator, auto break / A-skid skid indicator, } \\
\text { landing gear control lever, brake press, sliding table. }\end{array}$ \\
\hline 2 & $\begin{array}{l}\text { FMS guidance } \\
(\text { EFIS + PFD) }\end{array}$ & $\begin{array}{l}\text { Altitude acquired armed, AFS operational configuration, Mach } \\
\text { number, aircraft track (heading), selected altitude, actual airspeed } \\
\text { and speed trend, magnetic heading reference, altimeter baro, vertical } \\
\text { speed, aircraft attitude display }\end{array}$ \\
\hline 3 & $\begin{array}{l}\text { Configuration of } \\
\text { PFD position }\end{array}$ & Basic T position \\
\hline 4 & Display unit & $\begin{array}{l}\text { Primary flight display, navigation display, engine display, system } \\
\text { display, flight control unit, EFIS control panel, thrust levers and } \\
\text { engine control function, display management computer, ECAM } \\
\text { display (Upper and lower display) }\end{array}$ \\
\hline 5 & Mode of ND & ROSE, ARC, PLAN \\
\hline 6 & $\begin{array}{l}\text { Display } \\
\text { dimension of EFIS } \\
\text { (2 PFD and } 2 \text { ND); } \\
\text { ECAM technology }\end{array}$ & $7.25 \mathrm{in} \times 7.25 \mathrm{in}$ \\
\hline
\end{tabular}

Table 2. Advantages of A320 Multifunction Flight Display [18-24]

\begin{tabular}{ll}
\hline № & \multicolumn{1}{c}{ Advantages } \\
\hline $\mathbf{1}$ & Full digital display \\
$\mathbf{2}$ & Full computerized operations and protections (auto-tune) \\
$\mathbf{3}$ & Because it is full computerized, so, the operation need less input and response from pilot \\
$\mathbf{4}$ & Push button philosophy is simple with dark cockpit concept \\
$\mathbf{5}$ & When things are going well, the airbus is more comfortable to be flight \\
$\mathbf{6}$ & Cockpit visibility is better \\
$\mathbf{7}$ & Using the concept "need to know" while presentation about an information \\
$\mathbf{8}$ & ECAM technology, as checklist is effective (which has another function as guider instruction \\
& to do something if there is a problem shown) \\
$\mathbf{9}$ & Simple and functional \\
$\mathbf{1 0}$ & Ergonomic cockpit better than Boeing \\
$\mathbf{1 1}$ & MFD display simple than Boeing's MFD \\
\hline
\end{tabular}


Table 3. Disadvantages of A320 Multifunction Flight Display [22-26]

\begin{tabular}{ll}
\hline № & \multicolumn{1}{c}{ Disadvantages } \\
\hline $\mathbf{1}$ & Not yet has Vertical Situation Display (VSD) \\
$\mathbf{2}$ & $\begin{array}{l}\text { Flight control systems can not quite get things right when something going gets really rough } \\
\text { in terms of weather (turbulence and crosswinds) }\end{array}$ \\
$\mathbf{3}$ & $\begin{array}{l}\text { When things go wrong, the ECAM is a good idea but when the ECAM also has trouble, then } \\
\text { you find yourself going into a paper checklist (Airbus QRH very complicated to read) }\end{array}$ \\
\hline
\end{tabular}

\subsection{Flight Instrument of Boeing $737 N G$}

The common display system (CDS) supplies information to the flight crew on six flat panel liquid crystal display units (DU's). These displays include the two primary flight display (PFD); two navigation display (ND); upper display unit (showing: engine and fuel indications, crew alert messages); and lower display unit (showing: the capability, to switch between secondary engine parameters and hydraulic system information), as presented on Fig. 3, Table 4, 5 and 6.
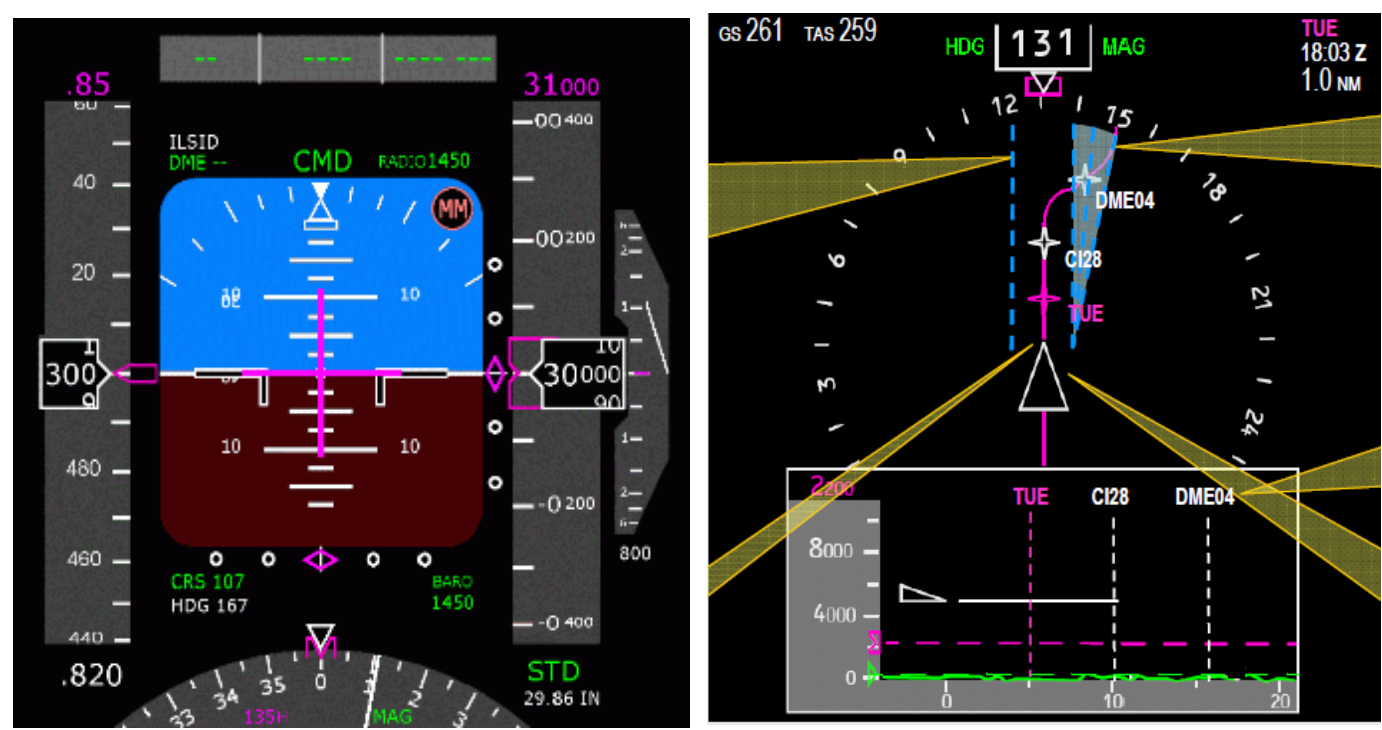

Figure 3. PFD and ND on B737 NG

Table 4. B737 NG multifunction display criterion

\begin{tabular}{lll}
\hline No. & \multicolumn{1}{c}{ Components } & \multicolumn{1}{c}{ Description } \\
\hline 1. & Common display system (CDS) & EICAS display (upper and lower), 2 PFD, 2 ND \\
2. & CDS control panel & EFIS control panel, display select panel, display source panel \\
3. & $\begin{array}{l}\text { Standby flight instruments and } \\
\text { control panel }\end{array}$ & $\begin{array}{l}\text { Magnetic compass, RMI, integrated standby display (attitude, } \\
\text { airspeed, altitude, magnetic heading, and approach } \\
\text { information) }\end{array}$ \\
4. & PFD guidance & $\begin{array}{l}\text { Flight mode annunciator (FMA), autopilot, flight director } \\
\text { system status, attitude director indicator (ADI), ILS indicator, } \\
\text { radio altitude indication, heading/track indication, } \\
\text { airspeed/Mach indication, vertical indication }\end{array}$ \\
\hline
\end{tabular}


Table 5. Advantages of B737 NG Multifunction Flight Display

\begin{tabular}{|c|c|}
\hline No & Advantages \\
\hline 1 & Display design is mix between analogue and digital display \\
\hline 2 & $\begin{array}{l}\text { The position of indicator/instrument switchable to another indicator/instrument (ex. PFD to } \\
\text { ND, ECAM to ND, and so on) }\end{array}$ \\
\hline 3 & Has the camera to control the situation in cabin (between gate/exit door and cockpit door) \\
\hline 4 & Better to control while things get rough in terms of weather (turbulence and crosswinds) \\
\hline 5 & When things go wrong, QRH is simple \\
\hline 6 & $\begin{array}{l}\text { When the trouble starts while flight, the Boeing offers a less sophisticated and more flexible } \\
\text { way out of the troubles and give more time to think about things }\end{array}$ \\
\hline 7 & Give enough and simple information about flight \\
\hline 8 & Has the Vertical Situation Display (VSD) \\
\hline 9 & Warning display very clearly \\
\hline
\end{tabular}

Table 6. Disadvantages of B737 NG Multifunction Flight Display

\begin{tabular}{|c|c|}
\hline No & Disadvantages \\
\hline 1 & ecause mix design or semi computerize, so, it is need more input and response from pilot \\
\hline 2 & $\begin{array}{l}\text { Overheating of an individual display unit will cause that unit to blank until it cools down } \\
\text { when it will return }\end{array}$ \\
\hline 3 & $\begin{array}{l}\text { Using paper checklist (memory item) because not yet has the ECAM like Airbus. Actually } \\
\text { Boeing has EICAS without instruction to solve the problem }\end{array}$ \\
\hline 4 & Heading on PFD not rigid and too many displays \\
\hline 5 & $\begin{array}{l}\text { Need to adding some information (such as fasten seatbelt } \mathrm{ON} \text {, fuel cross-feed } \mathrm{ON} \text {, and so on) } \\
\text { into MFD software }\end{array}$ \\
\hline 6 & $\begin{array}{l}\text { Screen display technology quick to heat, it will be better if changed it using energy saving } \\
\text { screen which not quick to heat }\end{array}$ \\
\hline
\end{tabular}

\subsection{Questionnaire Data Processing}

To get the real input or data from the users (pilots), the questionnaire to measure pilots' point of view about MFD and cockpit layout on the airplane that they fly has been made. The questionnaire using Likert-scale method and open/close questions to collect the information from the respondent(s). To answer the question on Likert-scale, respondent can give the checklist on one of the answer choices (SS=strongly agree/comfortable; S=Agree/comfortable; RG=Undecided; TS=Disagree/uncomfortable; STS=strongly disagree/strongly uncomfortable) [27].

The questionnaire consists of:

-17 questions (11 questions using Likert-scale, 5 open questions, and 1 close question)

- total respondent is 31 respondents (14 respondents for A320, and 17 respondents for B737 NG)

- respondents flight hours in range 1,500 to 15,000 .

The report of respondent's airline is presented on Figure 4. 


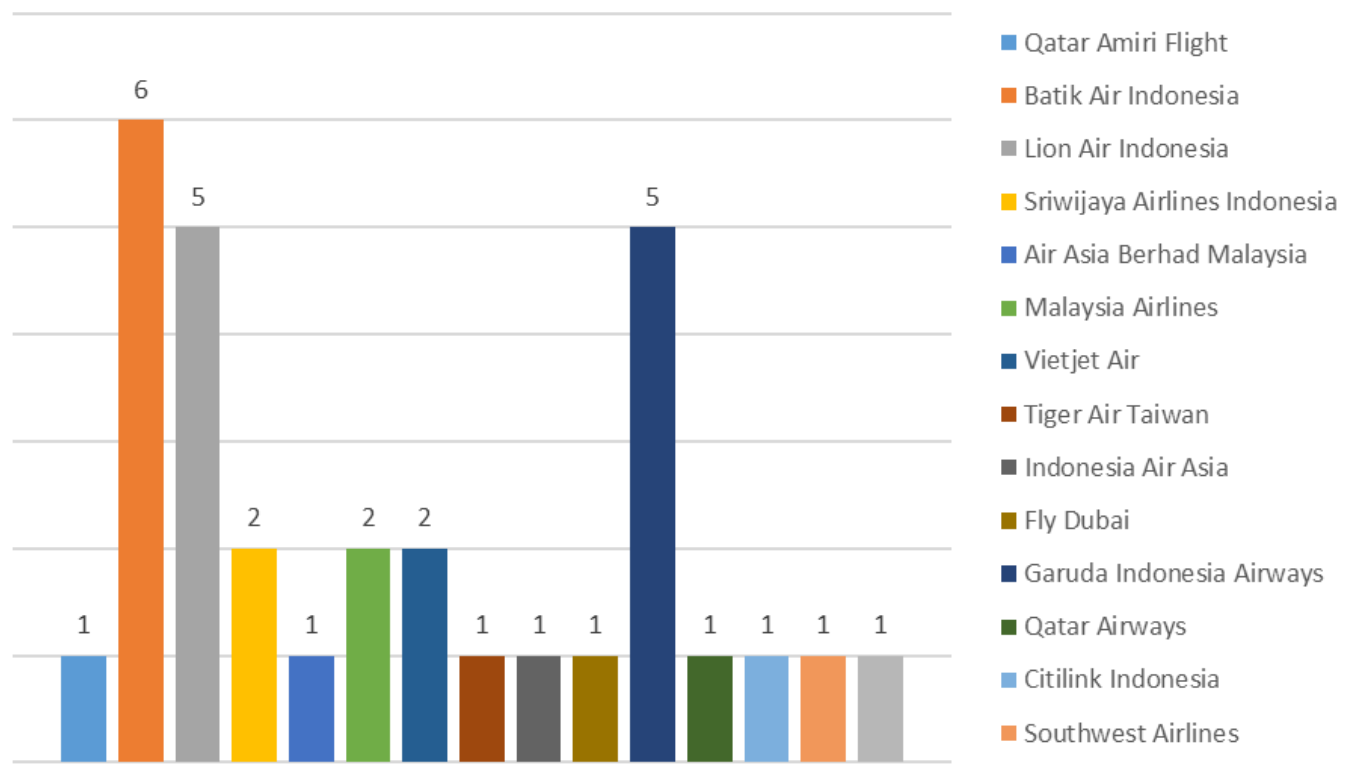

Figure 4. Respondent's Airlines

\section{Results and Discussions}

Based on cockpit layout, literature review, there are some findings as shown on Table 7-9 and Fig 5 .

Table 7. Technology of Flight Instrument Systems that Applied on A320 and B737 NG

\begin{tabular}{lll}
\hline № & \multicolumn{1}{c}{ A320 } & \multicolumn{1}{c}{ B737 NG } \\
\hline $\mathbf{1}$ & $\begin{array}{c}\text { The design of display position is using } \\
\text { model basic T }\end{array}$ & $\begin{array}{l}\text { The design of display position is using model } \\
\text { basic T }\end{array}$ \\
$\mathbf{2}$ & ECAM and EFIS technology & EFIS, EICAS and VSD technology \\
$\mathbf{3}$ & The push button philosophy & The toggle button philosophy \\
$\mathbf{4}$ & LCD technology on screen & LCD technology on screen \\
$\mathbf{5}$ & Glass cockpit technology & Glass cockpit technology \\
\hline
\end{tabular}

Table 8. Resume of the respondent's answers

\begin{tabular}{llc}
\hline № & \multicolumn{1}{c}{ Description } & Percentages (\%) \\
\hline $\mathbf{1}$ & $\begin{array}{l}\text { Respondents strongly comfortable with the flight instrument } \\
\text { display and multi-function display of the aircraft that they fly }\end{array}$ & 88.387 \\
$\mathbf{2}$ & $\begin{array}{l}\text { Respondents strongly like the flight instrument display and } \\
\text { multi-function display of the aircraft that they fly }\end{array}$ & 85.161 \\
$\mathbf{3}$ & $\begin{array}{l}\text { Respondents disagree that PFD and ND on the plane now is } \\
\text { still very complex and a lot }\end{array}$ & 63.871 \\
$\mathbf{4}$ & $\begin{array}{l}\text { Respondents' undecided if the PFD (primary flight display) } \\
\text { and ND (navigation display) is designed to be a display only }\end{array}$ & 58.05 \\
$\mathbf{5}$ & $\begin{array}{l}\text { The font size on the instrument display now strongly proper } \\
\text { and strongly comfortable read by respondents }\end{array}$ & 81.29 \\
$\mathbf{6}$ & $\begin{array}{l}\text { The respondents disagree if the position of the instrument } \\
\text { display now needs to be changed }\end{array}$ & 74.194 \\
\hline $\mathbf{7}$ & $\begin{array}{l}\text { Respondents agree if the standby ALT, standby ATT, standby } \\
\text { ASI merged into one display }\end{array}$ & 64 \\
\hline
\end{tabular}




\begin{tabular}{clc}
\hline $\mathbf{8}$ & $\begin{array}{l}\text { Respondents agree if the standby flight instruments (standby } \\
\text { magnetic compass, standby RMI, integrated standby display) } \\
\text { merged to be one display only }\end{array}$ & 65.333 \\
$\mathbf{9} \quad \begin{array}{l}\text { Respondents agree if the dimensions of the display (PFD, ND, } \\
\text { upper display, lower display, ECAM + engine warning, ECAM } \\
\text { + systems) need to maximize }\end{array}$ & 71.613 \\
$\mathbf{1 0}$ & $\begin{array}{l}\text { Respondents' undecided if ECAM + engine warning display } \\
\text { and ECAM + systems display is designed to be a display only }\end{array}$ & 58.667 \\
$\mathbf{1 1}$ & $\begin{array}{l}\text { Respondents' undecided if the upper display and the lower } \\
\text { display is designed to be a display only }\end{array}$ & 58 \\
\hline $\mathbf{1 2}$ & $\begin{array}{l}\text { Respondents who prefer using full digital display design } \\
\text { Respondents who prefer using display design which mix } \\
\text { between analogue and digital display }\end{array}$ & 25.9 \\
\hline
\end{tabular}

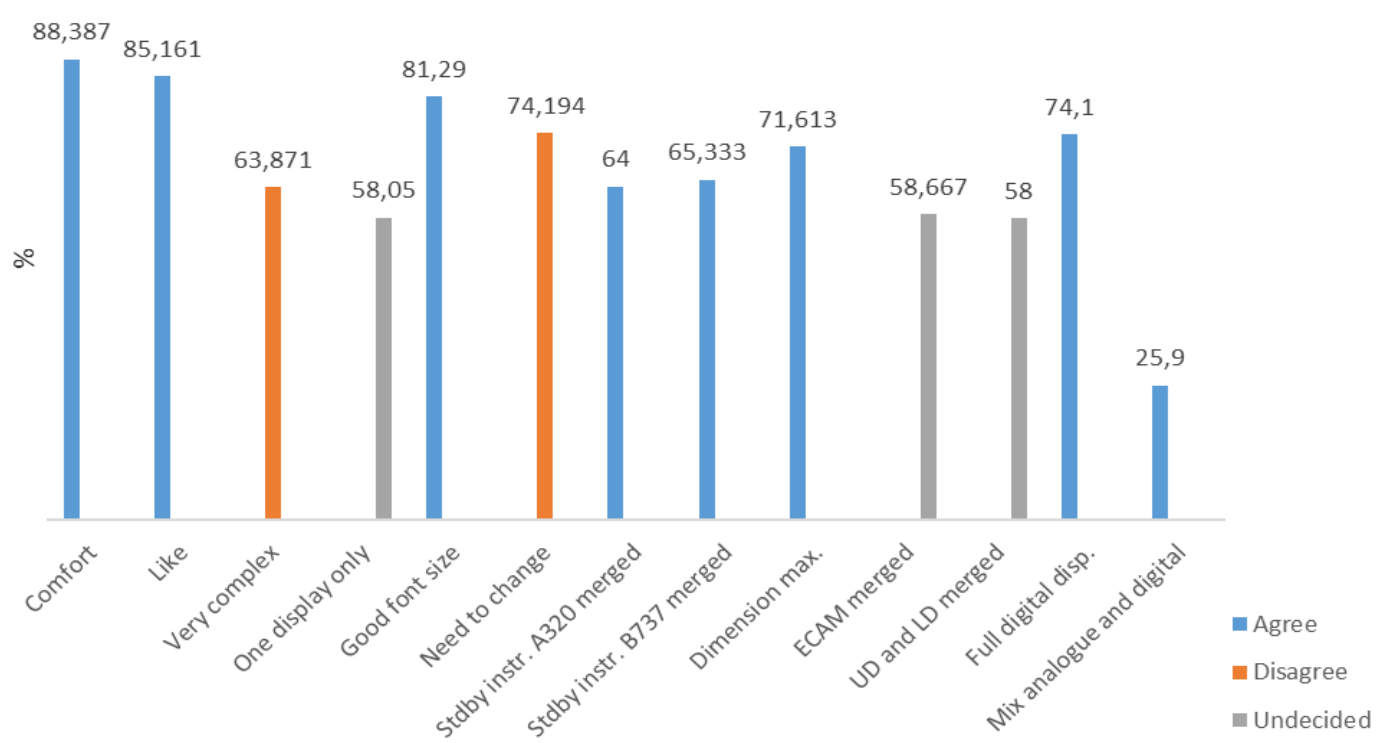

Figure 5. Percentage's Respondent's Response

This research gives some suggests/proposes as recommendations and/or requirements to design the new type model of flight multi-functional indicator as conceptual design, such as:

1. PFD and MFD typically combine several navigation instruments, and primary flight instruments (attitude, altitudes, VSI, ASI, direction indicator, turn indicator). And then, MFD may provide the same type of display as installed in the PFD position. So, how about if ND removed and merged with PFD, it can implication to the maximize of dimension of PFD.

2. And then, we can add some menu touch buttons to the PFD lower screen to show the ND, engine monitoring, and systems monitoring. Or we can merge ND and PFD into a large screen display.

3. To add ECAM to the new flight display design. And we can merge between ECAM + engine warning and ECAM + systems display (from A320), upper and lower display (from B737 NG) to be the one display only to maximize the dimension, then we can add some menu touch buttons to this display to show the instruction to solve the problem if that problem shown while flight.

4. The flight display layout uses the configuration basic T position.

5. Display design is using the full digital display and computerized system.

6. Standby flight instruments (standby magnetic compass, standby RMI, integration standby display) merged to be the one display only.

7. Uses the LCD screen technology.

8. Uses the VSD technology, which positioned for the PF and PM. 
Table 9. Recommendations and Requirements about New Design of Flight Display

\begin{tabular}{lll}
\hline № & \multicolumn{1}{c}{ Title } & \multicolumn{1}{c}{ Content } \\
\hline $\mathbf{1}$ & The flight display layout & \multicolumn{1}{c}{ Basic T configuration } \\
$\mathbf{2}$ & Display design & $\begin{array}{l}\text { Full digital display and computerized system } \\
\text { Touch button }\end{array}$ \\
$\mathbf{3}$ & $\begin{array}{l}\text { Display control access } \\
\text { Main flight display }\end{array}$ & $\begin{array}{l}\text { PFD (attitude, altitudes, VSI, ASI, direction } \\
\text { indicator, turn indicator, ILS) and MFD } \\
\text { (weather radar, terrain, ND) }\end{array}$ \\
$\mathbf{5}$ & Secondary flight display & $\begin{array}{l}\text { ECAM + engine warning indicator, ECAM + } \\
\text { systems indicator, the display's instruction to } \\
\text { solve problem }\end{array}$ \\
$\mathbf{6}$ & Third flight display & $\begin{array}{l}\text { VSD (waypoints, altitudes, climb/descend, } \\
\text { approach, terrain, failure flags }\end{array}$ \\
$\mathbf{7}$ & Standby flight display & $\begin{array}{l}\text { PFD, altimeter, RMI } \\
\text { Position of indicator characteristic } \\
\text { The position of indicator/instrument } \\
\text { switchable to another indicator/instrument } \\
\text { (ex. PFD to ND, ECAM to ND, and so on) }\end{array}$ \\
\hline
\end{tabular}

The VSD in B737 NG integrated into ND. So, the pilot can choose the menu he/she wants to show. In this new design, the author makes the VSD in one display alone (separate from ND). The purpose of the VSD is to present a clear graphical picture of the airplane's vertical flight path for enhancing the flight crews' vertical situation awareness.

On figures 6, 7 and 8, it proposes the new concept and technology of cockpit display layout based on analysis of cockpit display A320 and B737 NG. The advantages of the new display design that proposes by author are:

- make the pilot always interact with the display because it is an interactive display, so it can high-up pilot's awareness (pilot can choose type of information which he/she wants to see)

- shown the full size of the indicator which selected

- minimize overloaded information which received by pilot, because simple display

- the design and amount of indicator display relatives simple and not much, so it can help to improve data cross checking (flight data parameter presented relatively not much).

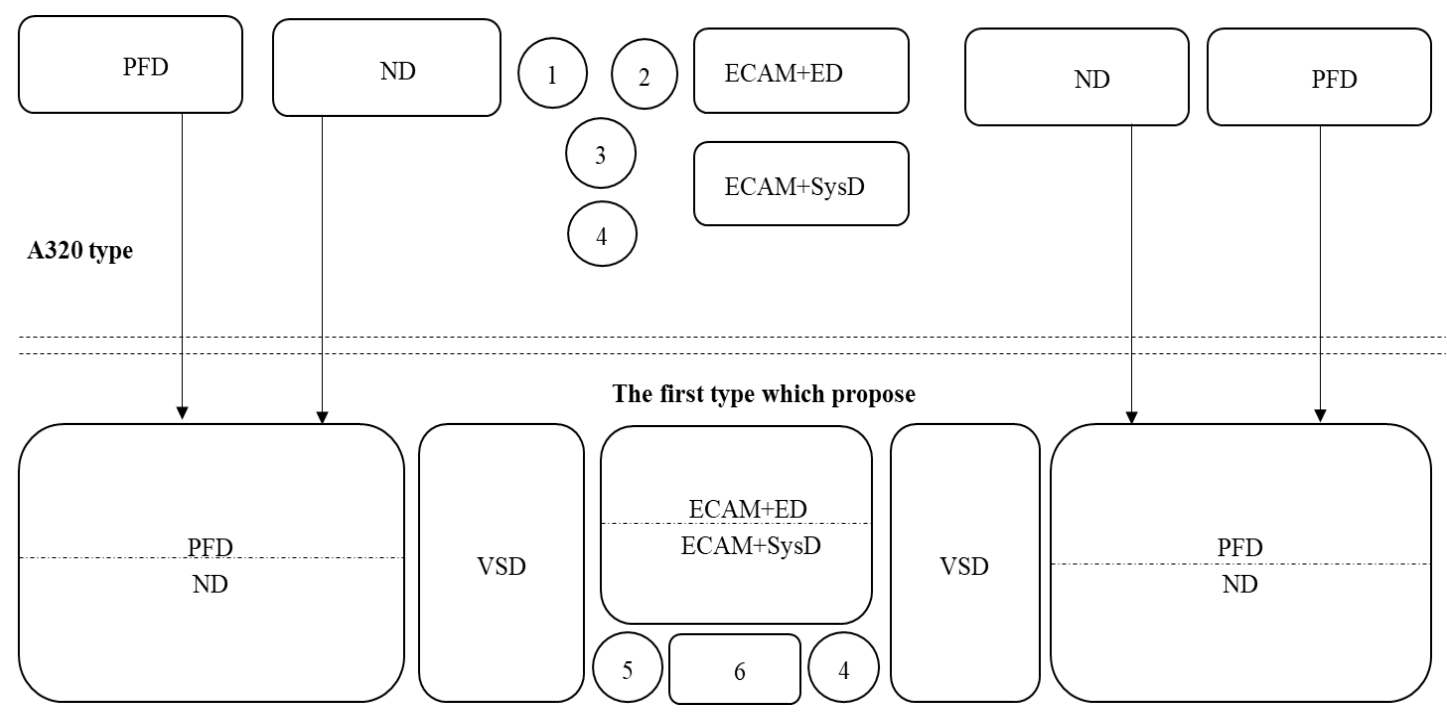

Figure 6. Transformations from A320 type to first type

Caption: 1. Stdby ASI; 2. Stby ALT; 3. Stdby ATT; 4. DME/VOR; 5. Stby RMI; 6. Stby PFD 


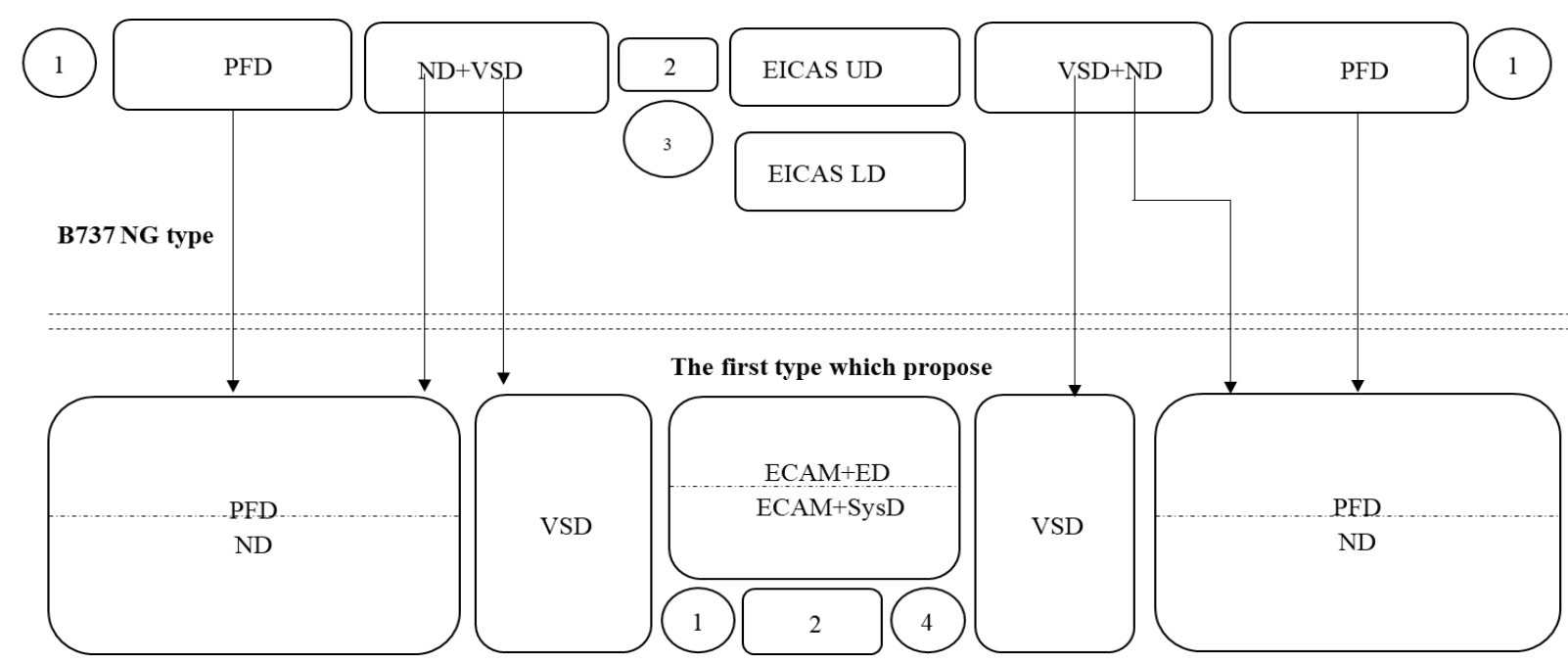

Figure 7. Transformation from B737 NG type to first type

Caption: 1. Stdby RMI; 2. Stby PFD; 3. Stdby Compass; 4. Stby DME/VOR
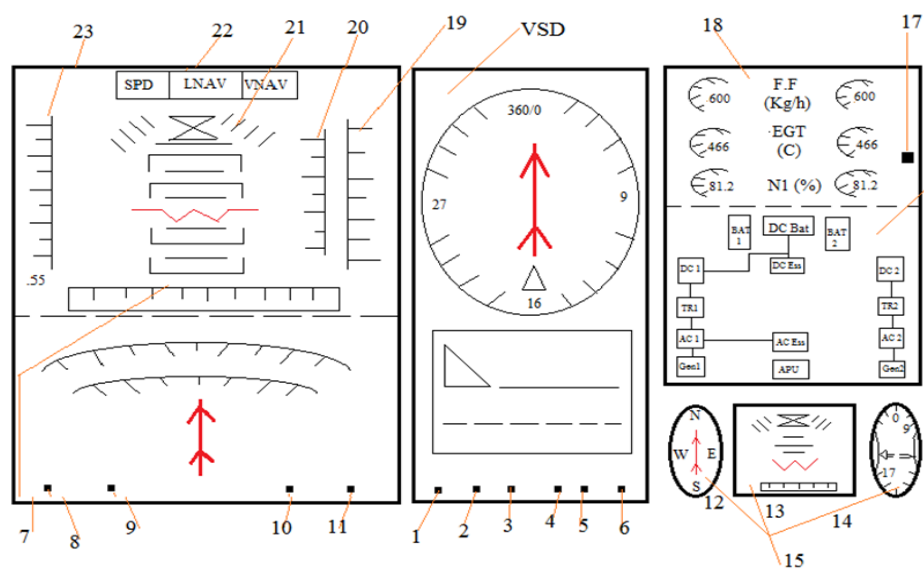

$17 \cdot 16$

Figure 8. The first visual design of cockpit display

Caption: 1. Button to show the waypoints on VSD; 2 . Button to show the altitudes on VSD; 3 . Button to show the climb/descend on VSD; 4 . Button to show the approach on VSD; 5 . Button to show the terrain on VSD;

6. Button to show the failure flags on VSD; 7. ILS on PFD; 8. Button to show the weather radar on MFD;

9. Button to show the terrain on MFD; 10. Button to show the full ND; 11. Button to show the ILS; 12. RMI

(standby); 13. PFD (standby); 14. DME/VOR (standby); 15 . Standby flight instruments $(12,13,14) ;$

16. ECAM + systems monitoring; 17 . Button to show the instruction to solve problem; $18 . \mathrm{ECAM}+$ engine warning indicator; 19. Altimeter on PFD; 20. VSI on PFD; 21. Altitude indicator (turn \& bank) on PFD; 22. Autopilot annunciators; 23. ASI on PFD.

In physically, this screen (ECAM) only one display, but separate to the two sub-screens. But if pilot choose the button number 17, the screen actually be one screen to show the instruction. And then, if pilot re-select this button, the screen will be two sub-screens again [28].

The PFD screen, and standby flight instrument always shown, although pilot push the button number 811. If pilot select one of these buttons (8-11), it will show the full screen one of them on MFD sub screen, and it is not affecting the PFD sub-screen. Physically PFD+MFD only one display, but separate to the two subscreens [28-29].

For the VSD, if the pilot selects one of these buttons (1-6), it will show the full screen one of them on VSD screen. The flight instrument standby and PFD+MFD and VSD use difference sensor and data input, as shown on Fig. 9 and Fig. 10. 


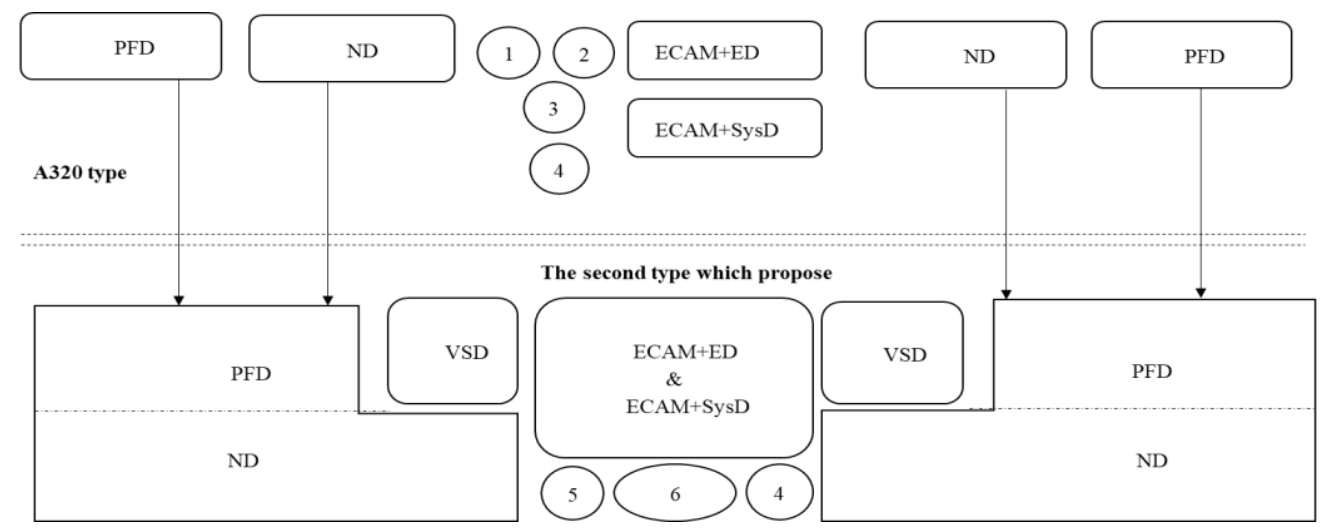

Figure 9. Transformation from A320 type to second type

Caption: 1. Stdby ASI; 2. Stby ALT; 3. Stdby ATT; 4. DME/VOR; 5. Stby RMI; 6. Stby PFD

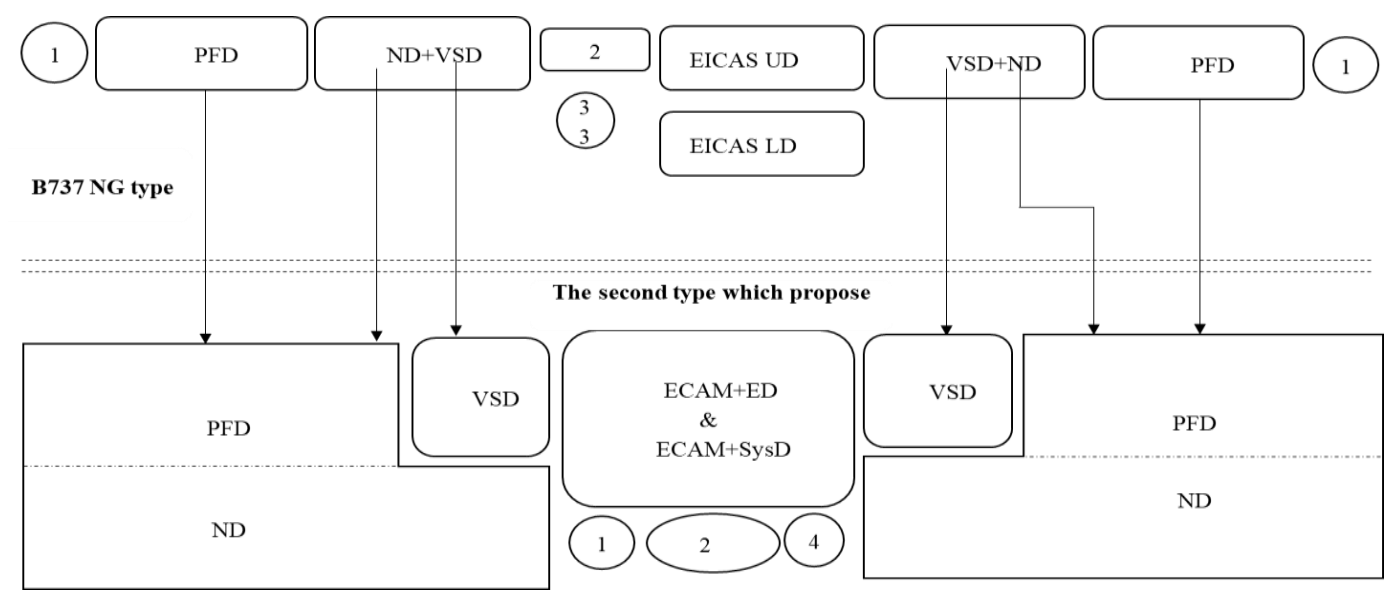

Figure 10. Transformation from B737 NG type to second type

Caption: 1. Stby RMI; 2. Stby PFD; 3. Stdby Compass; 4 . Stby DME/VOR

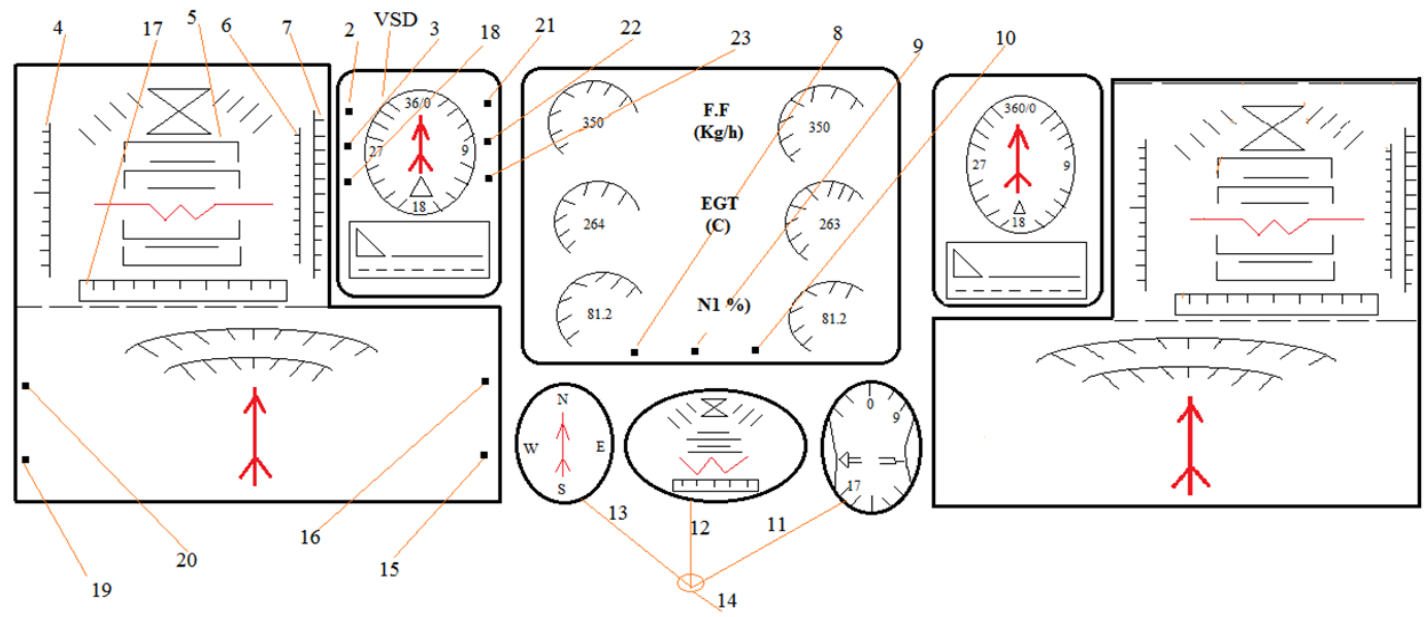

Figure 11. The second visual design of cockpit display

Caption: 1. VSD; 2. Button to show altitudes on VSD; 3. Button to show terrain and waypoints on VSD; 4. ASI on PFD;

5. Attitude indicator on PFD; 6. VSI on PFD; 7. Altimeter on PFD; 8. Button to show ECAM + engine warning;

9. Button to show ECAM + systems; 10. Button to show instruction to solve problem; 11. DME/VOR (standby);

12. PFD (standby); 13. RMI (standby); 14. Standby flight instrument (11,12,13); 15. Button to show full ND on MFD; 16. Button to show full ILS on MFD; 17. ILS on PFD; 18. Button to show climb/descend; 19. Button to show full terrain on MFD; 20. Button to show full WXR on MFD; 21. Button to show failure on VSD; 22. Button to show approach on VSD; 23. Button for the terrain on VSD. 
Physically PFD+MFD only one display, but separate to the two sub-screens. The PFD screen, and standby flight instrument always shown, although pilot push the button number 15, 16, 19, 20. If pilot select one of these buttons $(15,16,19,20)$, it will show the full screen one of them on MFD sub-screen, and it is not affected to the PFD sub-screen. For the ECAM's display, if pilot select one of those buttons (8-10), it will show one of those menus. For the VSD, if the pilot selects one of these buttons $(2,3,18$, $21,22)$, it will show the full screen one of them on VSD screen.

\section{Conclusions}

The finding in this study shows that the technology of flight instrument system between A320 and B737 NG visually displays similarity with several differences such as ergonomic side, ECAM technology, and VSD technology. Based on the responses from the users/pilots, finds and proposes several technologies or requirements to apply in new type model of PFD and MFD, they are including: PFD and MFD merged into one display only with some additional menu buttons; ECAM plus engine warning display, ECAM plus systems display, and digital instruction to solve the problem merged into one display only with some additional menu buttons; as well as the display design is using the full digital display, computerized system, LCD technology, VSD and EHSI technology, and layout display is using configuration "basic $\mathrm{T}$ ". Furthermore, a standby flight instrument merged into one display only with some additional menu buttons. From those findings, there are two proposed types of PFD and MFD layout or visual design.

\section{Acknowledgments}

This research was supported by Samara National Research University (Russia) and National Institute of Aeronautics and Space (LAPAN Indonesia).

\section{References}

1. Airbus. 1998. A319/A320/A321 Flight Deck and Systems Briefing for Pilot.

2. Aviation Training and Consulting. n.d. ATA 31: Instruments Displays B737 NG - Systems Course.

3. Boeing Company. 2002. B737-300/-400/-500 Operations Manual.

4. - - - 2018a. ATA Chapter 34: Navigation. Boeing Training and Professional Services FS009.

5. - - - 2018b. ATA Chapter 46: Onboard Network System -- Boeing Training and Professional Services FS009.

6. Brady, Chris. n.d. The Boeing 737 Technical Site: NG Flight Instrument http://www.b737.org.uk/flightinsts.htm\#NG_Flight_Instruments.

7. Federal Aviation Administration. 2011. Installation of Electronic Display in Part 23 Airplanes. USA. https://www.faa.gov/documentLibrary/media/Advisory_Circular/AC_23_1311-1C.pdf.

8. Kemdikbud RI. 2013. Aircraft Instrument And Autopilot Kelas XI.

9. SMARTCOCKPIT.com. $\quad$ n.d. B737 NG $\quad$ Flight https://www.academia.edu/35452539/B737_NG_Flight_Instruments_Do_not_use_for_flight.

10. [ATA 31: Indicating \& Recording. SJI Training Center B1/B2 Training Manual [Text]. - 2009-11-06 - Sukhoi Superjet International.

11. Coombs, L. (1999). Fighting cockpits 1914-2000: design and development of military aircraft cockpits. [Text] - Ramsbury, United Kingdom: Airlife Publishing.

12. Ergonomics of Aircraft Cockpit [Electronic resource] - URL: https://avionics-systemdesign.blogspot.com/2013/12/ergonomics-of-aircraft cockpit.html?showComment=1570077036648\#c1057643212538620307 [October 2019]

13. Flight Crew Operating Manual - Flight Instruments Bombardier Global 5000 (Volume 2, 11-00-6) [Text]. Bombardier Aerospace. 2005. 
14. Instrument Flying Handbook (FAA-H-8083-15) [Text] - US. Department of Transportation, Federal $\begin{array}{llll}\text { Aviation } & \text { Administration. } 2001 . \text { и } & \text { [Electronic resource] - URL: }\end{array}$ https://www.faa.gov/documentLibrary/media/Advisory_Circular/AC_23_1311-1C.pdf

15. Instrument Flying Handbook (FAA-H-8083-15B) [Text]. - US. Department of Transportation, Federal Aviation Administration. 2012.

16. Instrument Procedures Handbook (FAA-H-8083-168) [Text]. - US. Department of Transportation, Federal Aviation Administration. 2017.

17. Manual of Instrument Flight Procedure Design-DGCA 1/2013 [Text]. - Department of Civil Aviation Malaysia. 2013

18. Manual of Standards-Instrument Flight Procedure Design [Text]. - Civil Aviation Authority of Singapore. 2011

19. Medianto, Rully. Lecture material 9th: Flight Instruments [Text] // Rully Medianto // Adisutjipto College of Technology, Yogyakarta, Indonesia.

20. Moir, Ian. Allan Seabridge. Civil Avionics Systems [Text] // Ian Moir and Allan Seabridge // Professional Engineering Publishing Limited, London, UK. 2003

21. Parks, Eric. Airbus notes. Training Notes for A319/320/321 [Text] // Eric Parks // USA. 2019

22. Pilot compartment view design considerations [Electronic source] - URL: http://cafefoundation.org/v2/pdf_GFC/AGP.FAA.AC25.773-1.FieldofView.pdf - Federal Aviation Administration. 1993

23. Quality Assurance Manual for Flight Procedure Design - Validation of Instrument Flight Procedures [Text]. - ICAO Doc 9906 AN/472 volume 5. 2012

24. Recommended Practices and Guidelines for an Integrated Cockpit / Flight deck in a 14 CFR Part 23 Certificated Airplane [Text]. - General Aviation Manufacturers Association. 2004

25. Shirude, S.M., Jagtap, D.H., Design Review of Aircraft Cockpit for Aesthetic and Ergonomic Considerations [Text] // Shirude Shubham M, Jagtap Devendra H // 2017 // International Journal of Science and Research (IJSR), ISSN (Online): 2319-7064, Index Copernicus Value (2015): 78.96 | Impact Factor (2015): 6.391

26. Singer, Gideon. Methods for Validating Cockpit Design the best tool for the task [Text] / March 2002 / Gideon Singer - Royal Institute of Technology, Stockholm, Sweden. ISSN 0280-4646

27. Taylor, Henry. Effectiveness of Flight Training Devices Used for Instrument Training [Text] // Henry L. Taylor // 2005 // University of Illinois, Illinois, US.

28. Verhoeven, R.P.M., and A.J.C. de Reus. Prototyping interactive cockpit applications [Text] // R.P.M. Verhoeven, A.J.C. de Reus // 2004 // Nationaal Lucht- en Ruimtevaartlaboratorium National Aerospace Laboratory, Netherlands.

29. Wibowo, Teguh. Buku 1 Bahan Ajar: Aircraft Instrument [Text] // 2012 // Teguh Wibowo // Politeknik Negeri Bandung, Bandung, Indonesia.

This is an open-access article distributed under the terms of the Creative Commons Attribution 4.0 International License, which permits unrestricted use, distribution, and reproduction in any medium provided the original work is properly cited. 